\title{
What Is the Preferable Idea of Justice in Healthcare?
}

\author{
Lorena Forni \\ University of Milano-Bicocca, Milan, Italy
}

\begin{abstract}
When we talk about "health", we can understand very different meanings, if we refer to the Italian context, rather than the American one. In Italy, health is a fundamental right, and the healthcare system is a model for making this right concrete. In this paper, we will discuss how the American healthcare system is very different from a philosophical and bioethical point of view. We will try to figure out what reasons can be adduced to argue that "health" is a right and not a commodity like others on the market. This paper focuses on philosophical and bioethical issues related to health and healthcare, analyzed in both the Italian and American contexts. Emphasis will be given, using bioethical and legal arguments, to both concepts of health as a right and a good, taking into consideration the current economic and social crisis. In particular, the paper analyzes the theoretical models adopted by the two aforementioned countries and highlights fundamental differences between them. Analysis of the best and most fair allocation of resources leads to a proposal for new definitions for "resource" and preferable idea of justice for healthcare.
\end{abstract}

Keywords: right to health, fundamental rights, bioethics, justice, resources

\section{Health in a Fair Health System: Introductory Considerations}

The World Health Organization (WHO) in the "World Health Report 2000-Health Systems: Improving Performance” assessed the efficiency and quality of health services in 190 member states, concluding that Italy has the second-best healthcare system, after France. Italian healthcare management authorities welcomed this high-profile report with enthusiasm. Nevertheless, we should wonder whether nowadays the Italian health system can still be estimated as one of the best worldwide or if new trends are emerging from the constant request to limit public sector spending.

Without more recent data, it is impossible to reach a clear consensus. Unfortunately, no other publications have been released after the World Health Report in 2000, perhaps because of the intense debate it created. A different consideration can be formulated with regard to the perspective that emerges from the analysis of the Italian health system when compared to the American one, considered as another important model of providing health services.

As a matter of fact, the reconsideration of healthcare has a strong philosophical, bioethical, and legal relevance when we take into account different possible ways of promoting and protecting health. For the sake of clarity, health has a unique connotation in the European context, especially in the Italian one. While in the Italian judicial system, health is considered a fundamental right, in the USA, "health" is a good that depends on an individual's wealth and income.

Lorena Forni, Ph.D., Assistant professor of Philosophy of Law and Bioethics, School of Law, University of Milano-Bicocca, Milan, Italy. 
Thinking about models for providing health services, we notice a first meaningful association of terms examining the binomial justice-health. Hence, the first step is to clarify the different meanings attributed to the principle of justice regarding healthcare issues. The most popular definition, such as the definition proposed by H. T. Engelhardt, who (2001) considered fair every clinical practice realized implementing health policies that guarantee equal access to healthcare.

If we consider this definition comprehensive, we should believe that the principle of justice plays a central role and that it is a precise and uncontroversial guiding principle that can be used to bring an end to most of the healthcare policies and legal issues. However, this definition seems vague and ambiguous whereas strategies able to affect on clinical practice need to be identified in order to determine suitable ways of distributing resources and to guarantee equal access to healthcare.

Herein, a different redefinition of the principle of justice with regard to healthcare issues is proposed, moving from a critical consideration of Amartya Sen's theories. Going beyond traditional theories and classic definitions, justice has been redefined as the principle that considers ethically justified every clinical practice, which is realized by implementing healthcare policies that guarantee individuals' equal access to resources, whereas the evaluation of what is worth doing, being, or using contributes to determine equity itself.

Another important aspect that needs to be taken into consideration concerns the analysis of different models of healthcare systems in light of the respective qualification of "health". The substantial ethical-legal difference that characterizes "health" is reflected in the concrete procedures of the distribution of goods and services, especially within different healthcare models, that will be subject of bioethical analysis in this paper.

The fundamental question is about which healthcare model is fair as requested by citizens and thus provided by governments. This question is strictly linked to another issue: Which idea of "justice in healthcare" is preferable among those available in the current debate?

\section{The Importance of a Comparison}

In order to understand the perspectives given by connecting the equity dimension with providing health services, we need to take into account the broad range of meaning of "justice" whenever we are not persuaded by a general definition of justice in bioethics. This is in reference to citizens' equal access to goods, services, or therapies.

As maintained by Beauchamp and Childress (2013) and other authors (Chiodi, 2005; Pessina, 2000; Aramini, 2009), there are at least six different meanings of "justice" with regard to the right to health, that at the same time refer to contrasting models of health services distribution. It is possible to identify

a representative list of some major candidates for the position of valid material principles of [distributive] justice (though other lists have been proposed): 1 . To each person an equal share; 2 . To each person according to need; 3 . To each person according to effort; 4 . To each person according to contribution; 5 . To each person according to merit; 6 . To each person according to free-market exchanges. (Beauchamp \& Childress, 2013, p. 161)

There is not a sole purpose or a unique aim that we can pursue if we reflect on the typical model of providing health services, that is to say, the reference health system. With the expression, "health system”, we want to refer to a model of organization of persons, goods, and resources relevant to health. This model can be interpreted as a theoretical scheme chosen and/or created to represent or organize a class of phenomena, proposed to manage complex situations and able to influence concrete situations. The health system is not an entity, but a conceptual model kept by the researcher (Kleinman, 1981). 
On the contrary, analyzing the several implications given by the connection of justice with the right to health, there appear at least four different and conflicting purposes that a health system can pursue, namely (Engelhardt, 2001, p. 337):

1. The provision of the best possible care for all;

2. The provision of equal care for all;

3. Freedom of choice on the part of healthcare provider and consumer;

4. Containment of healthcare costs.

Depending on the purpose considered just and worth to be realized, there are various ways to make the right to health effective, creating at the same time different models of health systems (Cipolla, 2007). For example, if we pursue the aim stated with Point 1, i.e., the provision of the best possible care for all, it would be difficult for equal provision of care, goods, and therapies for all and freedom of choice of healthcare for both providers and consumers.

If we pursue, instead, the aim stated with Point 2, i.e., the provision of equal healthcare for all, the purpose that prefers free choices since they are just would be compromised and unattainable. Moreover, in this scenario, it would not be granted a real costs control.

Different ways of providing goods and services do not only correspond to contexts within different cultures and social policies. The qualification of public health services reflects above all theoretical models, qualifying the right to health and identifying what has to be considered just.

At this point, we need to inquire which bioethical and legal principles are singled out in the two different American and Italian contexts and whether or not they run at odds with each other. This is necessary in order to bring forth different models for healthcare systems.

\section{Philosophical Analysis of United States' Model}

The American context can be effectively proposed taking into consideration the position maintained by Engelhardt. The various references to Engelhardt's theoretical contribution can be explained by considering that amongst the scholars that researched on the role of justice in bioethics, he is the one who mainly treated the principle of justice in a systematic way, recognizing it as an important criterion to be examined in a transversal way as regards to a number of bioethical issues especially in the American context. With this regards, we can recall other scholars, such as Peter Singer and David Lamb, whose contribution to the bioethical debate on fair choices and procedures is limited to specific issues. Singer (1995; 2001), for example, faced the problem of justice with regard to animal testing. David Lamb (1990; 1985) was mainly interested in allocative profiles of organ transplants or in health services for patients in a persistent vegetative state.

Engelhardt pays particular attention to the specific profile of healthcare maintaining a clear and somehow radical position. The theory described by Engelhardt is the following: "A basic human right to the delivery of healthcare, even to the delivery of a decent minimum of healthcare, does not exist” (Engelhardt, 2001, p. 336). Engelhardt (2001) identified several and distinguished positions on the concepts of equality, justice, or fairness in the healthcare context, assuming that there are good reasons to cease the debate on these concepts and to face, on the contrary, our concerns about health through the identification of different levels of insurance against diseases and death risks. The main problem comes to light from this assumption, representing the real concern that needs to be addressed with regard to the issue raised by the principle of justice in healthcare. The appeal to this principle may imply reflecting on matters related to allocation of resources as well as considering the right 
to health as a right to healthcare and to the supply of health services, too ${ }^{1}$.

The passage cited above where Engelhardt does not recognize the existence of an actual right to healthcare is quite famous and it has been cited by several scholars (Muehlebach, 2012; Ferrera, 2005) ${ }^{2}$, who stressed the contractual logic implied by this position.

For that matter, a contractual and commercial structure characterizes American health services as mainly entrusted to private subjects, excluding almost totally public healthcare interventions. After all, the prevalence of economic logic clearly appears in the suggestion to work towards the reconsideration of health insurance plans rather than critically evaluate the introduction of new rights for citizens.

As a consequence of Engelhardt's statement, most of the population do not have access to fair healthcare, resulting in far more citizens needing emergency care when treatments become necessary. Consistently, with the policies belonging from the American context, which is characterized by heavy theoretical and practical differences compared to the European model, the author maintains that health is not a real human right, but should be considered a good among others in the market economy. On that basis, an optimal management of supply and demand depends on the subjects' overall economic possibilities, meaning that the margins of allocative efficiency are mainly determined by private management of health services (i.e., health policies ${ }^{3}$, investments funds, etc.), which exclude or strongly limit public intervention.

The arguments proposed by Engelhardt try to demonstrate that a fundamental human right to the delivery of a decent minimum of healthcare does not exist. He qualifies the right to healthcare as a claim right, meaning a right, which entails responsibilities, duties, or obligations on other parties regarding the right-holder. The author argues that

rights to healthcare constitute claims against others for either services or their goods. Unlike rights to forbearance, which require others to refrain from interfering, rights to beneficence [rights to healthcare] require others to participate actively in a particular understanding of the good life. (Engelhardt, 2001, p. 336)

Engelhardt (2001) stated that, since rights to healthcare imply someone being obligated to do something, rights to healthcare could be enforced only if public healthcare is considered a goal or a common value. Engelhardt does not relate the right to health with the principle of autonomy. That entails a first problem, since it encounters the difficulty of reconciling public policy interventions, aimed at limiting individuals' freedom, with citizens' bargaining power that has a primary and overarching role in the US context. Additionally, the author affirms that the right to health is not founded on the principle of autonomy. Rather, he considers the right to health as expression of the principle of beneficence, since it is the result of ethical and political choices aimed solely at guaranteeing a minimum of social and claim rights for the "well-being", financed by public expenditure. Engelhardt (2001) considered health a weak right, which is little more than a mere moral expectation that arises from "social sympathies" in limited contexts, whose maxim is: "do to others their good" (p. 87).

However, the range of goods to be achieved and harms to be avoided is extensive and complex. Hence, the author believes that the consideration of beneficence as a general criterion for bioethical issues underlines two

\footnotetext{
${ }^{1}$ In addition to Engelhardt's contribution on fairness and justice related to the allocation of health resources we could recall Brock, Daniels, \& Callahan (1989); Daniels \& Sabin (1997); and Daniels (2010).

${ }^{2}$ With reference to the crisis in the American health system and to the reform proposed by President Obama in 2008, see Hill (2012) and Dawes (2016).

${ }^{3}$ With regard to the complex system of health policies in the US system, see Austin \& Hungerford (2009).
} 
major difficulties. It would be complicated establishing in a pluralistic and secular society: (1) the content of goods to be achieved and harms to be avoided; and (2) the authority to impose a particular idea of beneficence, "including the identification of the circumstances under which inconveniences or contrary inclinations properly excuse one from discharging a duty of beneficence" (Engelhardt, 2001, p. 75).

The moral community that considers health a value to be promoted through public policy choices as well as a good to be achieved, is a limited and particular community ${ }^{4}$ included in a broader moral community of exchanges and agreements between subjects. If we consider these premises valid, we can understand why the author maintains that rights to healthcare depend on the principle of beneficence rather than on the principle of autonomy, unless they are derived from special contractual agreements. Hence, they may conflict with the decisions of individuals who may not wish to participate in the realization of a particular healthcare system. Private property is a superior right compared to duties of social and economic solidarity and/or duties of contribution to a public goal considered prevailing with respect to (legitimate) private goals.

Sacrifice of part of one's own goods to create a public system-a minimum and free system - that guarantees health for all is not part of common ethical and social assumptions. "If the resources involved in the provision of healthcare are not fully communal, private owners of resources may rightly have other uses in mind for their property than public healthcare” (Engelhardt, 2001, p. 336).

\section{The Italian Healthcare Model: A Theoretical and Normative Point of View}

One of the theoretical reasons that justify the particular relationship between "health" and "justice" is the declared juridical qualification of the right to health. In this regard, the Italian legal framework confirms the right to health at the highest level of legal sources, in Article 32 of the Constitution of the Italian Republic. It is the only right in the Constitution that is specifically considered "fundamental". Article 32 states that:

The Republic safeguards health as a fundamental right of the individual and as a collective interest, and guarantees free medical care to the indigent. No one may be obliged to undergo any health treatment except under the provisions of the law. The law may not under any circumstances violate the limits imposed by respect for the human person.

Whenever we talk about “fundamental rights”, we refer to the definition given by Luigi Ferrajoli ${ }^{5}$ (2001; 2007) referring to all the subjective rights, confirmed (mainly) at the constitutional level, that universally pertain to every human being as endowed with the status of person, citizen, or person with legal capacity (Ferrajoli, 2013). Similarly, it is appropriate to define subjective rights as every positive (to achieve services) or negative (to avoid harm or impediment) expectation ascribed to a subject by laws (Ferrajoli, 2014).

\footnotetext{
${ }^{4}$ Engelhardt affirms, "The morality of welfare and social sympathies, which is summarized under the rubric of the principle of beneficence, discloses the nisus of morality, the interest in securing the good of persons and of sentient beings generally". Nevertheless, "because of the unlikelihood of a general agreement about what is the proper concrete understanding of the good life, the question of what is good or bad to do cannot receive concrete answer. The question rather becomes heuristic: It aims individuals toward as rationally justifiable an account as possible of good and bad consequences. [...] The best one can do is to articulate the principle of beneficence, Do to others their good, in the concreteness of particular moral communities. Particular understandings of good and harm must be pursued, while not forgetting the absoluteness of the general concern for doing good and avoiding evil. The principle of beneficence is thus dialectical. [...] The principle reminds one that even when absolute answers are not available, relative ones will still be of importance to those who live within a particular moral community. The contradiction is overcome in a realization of the earnestness of the task of living a concrete understanding of the good life" (Engelhardt, 2001, pp. 80-81).

${ }^{5}$ Born in Florence in 1940, Luigi Ferrajoli is considered one of the most famous theorists of the Italian law. After his career in the Italian magistrature, he became full professor in Philosophy of Law. His books and essays have been published in different languages and are well-known especially in Spain and Latin America.
} 
Thus, we can affirm that the right to health is a subjective legal condition, confirmed at the highest level of legal sources, that pertains to every human being as endowed with the legal status of person ${ }^{6}$, citizen, or person with legal capacity, strictly connected with two other fundamental rights, namely the right to self-determination and the right to personal liberty.

The right to health in the Italian legal framework does not only concern an individual dimension, but it has a collective importance and, at the same time, it has to be considered a fundamental liberty and social right ${ }^{7}$.

The reference to the right to health as a social right means highlighting the prescriptive nature of the legal rule aimed at providing the State with duties of intervention and warranties. The State, briefly, must supply support, services, and cares; it must realize and improve a network of protection and activities to make concrete the right to health meant as a claim right.

Moreover, we need to clarify that the right to health has to be interpreted also as the right not to suffer. In order to define "health", we can provisionally adopt the notion given by the World Health Organization (WHO) that considers health "a state of complete physical, mental and social well-being and not merely the absence of disease or infirmity” (WHO, 1948, p. 1).

If, on the one hand, the right to health can be considered exclusively a social right; on the other hand, it cannot be confined in the range of liberty rights, meant only to claim positive or negative autonomy with reference to interventions on one's own body.

In the Italian legal system, the fundamental right to health concerns both the individual perspective and the public context; it pertains, additionally, not only to free and autonomous choices for care, but also to all the practical guarantees necessary to realize this fundamental right.

Contrary to what is maintained by Engelhardt, the Italian legal framework recognizes the fundamental right to claim and achieve healthcare, since it considers fundamental the individual's right to choose whether he/she wants to seek healthcare or not, as well as the duty of public healthcare providers to guarantee appropriate support and free healthcare to indigents.

It is a right that prevails on property rights and on patrimonial and commercial rights, and it cannot be removed because of political decision. The importance of Article 32 of the Italian Constitution needs to be highlighted not only because it is the first and most important rule of law that justifies and legitimates medical practice, but also because it must be the legal reference when we wonder about decisions or we face choices of health policy that strongly limit resources (economic or not) made available for the guarantee and the execution of the aforementioned rights.

\section{When Can We Talk About a Fundamental Right to Healthcare?}

The assertion of the right to health and of the consequent subjective right to healthcare as a fundamental right depends on the relevant ethical-legal or political-legal system. In the Italian context, every level of governance must take into account the limits originated by the prescriptiveness of Article 32 of the Constitution and imposed to public powers by an absolute right that combines the principle of autonomy with the principle of beneficence. The Italian superior Courts, for example, consistently interpreted the right to health as a right

\footnotetext{
${ }^{6}$ The fundamental right to health belongs to all the individuals without discrimination of legal or social conditions. That means, for example, that the right to health must be guaranteed also to migrants, whether or not they have a valid residence permit.

7 See the judgment of the Italian Constitutional Court n. 438/2008.
} 
above the governance, which does not have the power, even for public reasons, to weaken or jeopardize it ${ }^{8}$.

Nevertheless, we still need to clarify which model of healthcare is more in accordance with the principle of just access to healthcare resources, if we accept that the fundamental right to health is able to affect private relationships as well as to limit public powers.

Going back to Engelhardt's provocation, we must recognize that he is not inaccurate when he states that a fundamental right to a decent minimum of healthcare does not exist. In fact, we should distinguish the level of rules of law in force in the United States from the level of bioethical analysis. A constitutional article that considers health a fundamental human right as well as a collective interest does not exist in the US. Even Courts' judgments did not recognize the existence of this right or declared the duty of guaranteeing free healthcare to indigents. Engelhardt describes the situation of his own legal and social system, but at the same time he doubts, at the theoretical level, whether this fundamental right could be recognized. The author maintains that hypothetical rulings issued by public powers in favour of citizens' health could be envisaged. These actions, however, should be considered as laid down by beneficence and, as such, limited to defined circumstances where the community is aimed by the will of doing to others their good. Engelhardt expresses a moral evaluation not entirely positive with regard to public healthcare interventions, since he considers a sacrifice to members of the community to make available to everyone a decent minimum of healthcare.

Hence, we can notice a radical difference between the Italian and the American models, both in the bioethical analysis and within the legal framework. The substantial difference does not consist in the fact that in the USA the right to health is not a constitutional right, rather in the fact that private property is considered logically and legally superior if compared to every good or public goal. Moreover, there are no elements of critical analysis that could influence ethical and bioethical debates on this issue. For that reason, it seems unlikely an upheaval, or a change in the short period, of the bioethical context, as well as the introduction of constitutional laws that may approve new fundamental human rights.

Since 2012, the Italian healthcare system, as outlined by the Law 833/1978, is inspired by the principle of self-determination, even though it is strongly influenced by equitable goals ${ }^{9}$. In fact, it is characterized not only by free healthcare for indigents, but also for having balanced the aforementioned goals. We can maintain that the Italian healthcare system is a model that offers everyone a decent minimum of healthcare and, at the same time, establishes that individuals can decide which quota of their private resources might be used for those services not included in the first level of healthcare.

With reference to the American healthcare system, which is deeply characterized by liberalistic elements, we could wonder how protection of health is combined with the level of healthcare guaranteed by health facilities. Engelhardt undoubtedly considers the principle of autonomy prevailing on healthcare, so that he promotes it as the only relevant criterion while determining the levels of healthcare that have to be satisfied. At the same time, he states that social beneficence has a marginal role. When the author makes reference to the principle of beneficence with regard to healthcare policies, he ascribes a specific meaning to that principle. He refers not only to ethical practices aimed at benefiting patients, but to interventions/goods/services financed by public resources that influence those action and choices that individuals are not able to access with their own resources. Moreover, Engelhardt considers that the empowerment of public policies to manage healthcare and

\footnotetext{
${ }^{8}$ See judgments of Superior Italian Courts, mentioned in Forni (2016).

9 Since the end of the 70's the National Healthcare Service has been revised twice during periods of deep economic and social crisis. For a more detailed analysis of the Italian model, see de Belvis, A. G. et al. (2012) and Turati (2012).
} 
resources means downsizing individuals' freedom to choose how to supply or receive cares and services. In fact, the US system neither pursues healthcare distributed in the same way to every citizen, nor advocates providing the best healthcare possible to everyone. On the contrary, it is looking forward to protecting the free convergence of supply and demand for health goods and services, without neglecting cost control for basic care. The American model is mainly founded on private choices and free trade. It is a consolidated model that considers freedom of choice as the first and fundamental criterion for the organization of the whole healthcare system. The level of distribution of health services to which one could access depends on capacity and free allocation of individual resources. The US healthcare system is founded on the individualistic principle of private property and wealth within which, as Engelhardt clarified, the possibility to access to healthcare is articulated. Additionally, we need to recall that health in the theoretical-legal perspective is not a right which includes constitutional guarantees. Additionally, regulatory interventions on this topic are sporadic ${ }^{10}$ and mainly aimed at establishing socio-economic and contractual conditions to achieve services ${ }^{11}$, rather than intended to modify or guide public policies. We need to remind ourselves that in the US health is a good; the legal protection of this good cannot be obtained through the exercise of a subjective autonomous right ${ }^{12}$, but through the exercise of the right to privacy (Borsellino, 2018) ${ }^{13}$. The other essential theoretical basis that contributes to understand the radical difference between the American and the Italian healthcare systems (Morley-Fletcher, 2013; Atlas, 2011) can be found in the redefinition of the principle of justice related to subjective legal positions relevant to healthcare.

According to Engelhardt, a health system might be considered just if there is the possibility to freely choose providers, consumers, and services. Even though the author refers to autonomy, when he takes into consideration preferable models of social organization autonomy takes on the limiting meaning of economic-contractual freedom. Starting from this premise, Engelhardt structures his argument is a paradoxical way. In fact, on the one hand, he seems to exacerbate the autonomist profile in the American healthcare system (Pozgar, 2012; Pence, 2004), reducing the bioethical principle of autonomy to contractual autonomy and individual wealth. Therefore, his argument considers individual autonomy as something related to freedom to choose and to access the best level of care allowed by private resources. On the other hand, Engelhardt recognizes the need of public interventions aimed at providing a minimum level of healthcare. However, he

\footnotetext{
10 The first regulatory intervention was made by President F. D. Roosevelt, who on August 14, 1935 issued the Social Security Act that introduced in the New Deal field, compensations for unemployment, disease, and old age. The program Aid to Families with Dependent Children was born within those circumstances. The ruling was financed by contributions from employers and employees as well as by funds of Federal balance sheet. The Social Security Act underwent various changes over the years, but the most important ones were those approved by President L. B. Johnson in 1965, that created two healthcare programs, namely Medicare and Medicaid that are still operative. President B. Obama worked towards a radical reform of the healthcare system that he started to outline since 2010. After a troubled legislative procedure part of the reform, namely the Health Insurance Exchange, entered into force on October 1, 2013 aimed at making the healthcare insurance market more accessible, competitive, economical, and transparent.

11 In the US, there are two public healthcare programs, i.e., Medicare and Medicaid. For additional information, see https://www.medicare.gov and https://www.medicaid.gov.

12 In the 70', the Court of New Jersey ruled the case of Karen Quinlan, a young girl in a permanent vegetative state, recognizing that her parents were entitled to exercise the right to privacy on behalf of their daughter. The Court acknowledged their authority to carry out her will not to be kept artificially alive on the base of the argument that privacy amounts also in the event that a patient does not want the State to interfere in decisions relevant to one's own life and personal choices. See In re Quinlan (70 N.J. 10, 355 A.2d 647 (NJ 1976)).

${ }^{13}$ Since the famous judgment of the Supreme Court of the United States of America in 1973 related to the case Roe vs. Wade, where the right to abortion was linked to the right to privacy, the concept of privacy has been considered as a right whose object is individual's bodily integrity, as well as physical and psychological freedom.
} 
maintains that those interventions do not have the purpose of enhancing individuals' autonomy on healthcare choices (establishing which are the specific duties of state or federal interventions, and, for example, qualifying health as a subjective right), but they rather have the only purpose of "doing to others their good", or achieving the best interests of persons. To a European, scholar appears paradoxical the idea of considering just a model aimed at emphasizing individuals' autonomy, as well as the right of access to the best possible healthcare when, at the same time, public institutions' obligations are not focused on the amendment of social inequalities. When Engelhardt refers to the principle of beneficence in public issues related to healthcare services, he maintains that doing to others their good or working for the best interest of the others means implementing residual interventions with limited public resources in order to create a social security network only in case of defined circumstances.

The author states, instead, that freedom, considered both as freedom of choice and as economic freedom, is the value on which the principle of autonomy is founded. Regarding this preliminary clarification, Engelhardt proposes, even though not explicitly, an auxiliary and almost ancillary idea of justice with respect to autonomous healthcare choices.

In this regard, he affirms that

The more one endorses freedom-based view of justice, the more one will be committed to support freedom in the choice of healthcare provider, consumer, and services. The more one endorses a goals-based view of justice, the more one will be committed to achieving such goal as the best care for all (Engelhardt, 2001, p. 354).

This means that a restriction of individuals' autonomy imposed by public goals is not justified, therefore it cannot be considered just. Briefly, a healthcare system that aims at restricting the market and the equilibrium between contributory capacity to access healthcare and individual's needs in order to achieve services would be strongly unjust.

Even though the American legal framework proposes a healthcare model built on the idea that justice concerns individual capability to obtain high-level health services founding subjects' autonomy on their contractual capacity (meaning that it is just, thus fair, that greater economic possibilities entail higher standards of services), it should be noticed that nowadays we are witness of a countertrend attempt. In fact, the US government, through interventions of the latest presidencies (Oberlander, 2009; Andersen, Rice, \& Kominski, 2007; Obama, 2016) ${ }^{14}$, tried to restrain contractual liberty in favour of the needs of millions of Americans to achieve primary healthcare (De Navas-Walt, Proctor, \& Smith, 2013) ${ }^{15}$.

Despite attempts by the current presidential administration to strongly change the Obamacare (AMA, 2017), the model introduced seems to give appreciable results.

The US model seems a faraway reality because of the different legal structure that distinguishes it from the Italian model and its reference values and principles.

\footnotetext{
${ }^{14}$ In particular, President Obama promoted a different health culture and proposed a more fair access to health services, especially for the less privileged population.

${ }^{15}$ Healthcare services are supplied only to those citizens covered by healthcare insurance. According to statistics of the US Census Bureau, the percentage of people covered by employment-based health insurance in 2012 were not statistically different from 2011, at 54.9\%, the percentage of people covered by government health insurance increased to $32.6 \%$ in 2012 from $32.2 \%$ in 2011, and in 2012, the percentage of people without health insurance decreased to $15.4 \%$ (48 million) from $15.7 \%$ in 2011 . In 2012, the percentage and number of uninsured children under age 18 decreased to $8.9 \%$ and 6.6 million, down from $9.4 \%$ and 7.0 million in 2011.
} 
However, if we think about the current emphasis on the control of public expenditure in Italy, that is, considered mainly as healthcare expenditure, the American model does not appear so distant.

Let us consider a radical restructuring of the Italian model to make it resemble the US one. The aim could be, formally, the will to contain public costs of healthcare services. The first consequence would be the removal of the purpose of providing equal services to all the citizens while increasing the quality of healthcare services only for those persons that can afford them. Thus, the "best possible healthcare" would be achievable through a model based on the principle of free individual choice. This means stressing a competition between private subjects in order to achieve, on the base of owned incomes and goods, the best healthcare services available on the market, as it happens in the American model. The hypothesis of a new model transforms health from a "right" to a "good" to be earned and protected, and, at the same time, it entails the loss of the public importance of health hiding its qualification not only as fundamental human right, but also as collective interest.

\section{Which is the Preferable Healthcare Service?}

After having described the profound ethical and legal differences between the American and the Italian healthcare systems, it is necessary to critically evaluate the reason why a different definition of "justice" could benefit the reflection on healthcare models. At the beginning of this paper, it has been anticipated that the meaning of justice that we refer to is related to Sen's (2009) theory of just allocation. He maintains that the evaluation of justice in resources allocation should be estimated making reference to individual's general advantage. According to classical theories (utilitarianism, liberalism, and neo-contractualism), "advantage" is a term that has been related for a long time to a wide range of expressions, such as "personal utility", "happiness", "individual pleasure”, “assets”, “income”, “just wage”, etc. Sen (2009) proposed an original re-definition of the meaning of advantage, stating that "individual advantage is judged in the capability approach by a person's capability to do things he or she has reason to value” (p. 231). "Advantage” is a term that allows us to attribute value to something on the base of real or potential elements owned by one or more subjects at certain conditions. Sen specifies that the expression "attribution of value” means firstly "what is worth doing/being". Secondly, Sen (2009) considered that the "attribution of value" corresponds to another way to identify resources. Starting from these elements, the evaluation of "what is worth", otherwise "a resource", becomes an articulated judgment that compares subjective evaluations with rules established in a specific context. According to Sen (2009), the estimate of what in a concrete situation represents a personal advantage for the subject means establishing what has to be considered a resource.

Therefore, a healthcare policy ethically justified would be a policy that promotes clinical practices and/or services that guarantee fair access to resources, whereas the evaluation of what is worth doing, being, or using as a resource contributes to the determination of equity itself. According to the Italian model, it is worth investing and using public resources in order to supply healthcare services. In Italy, the just model considers health as a right that neither can be altered by economic needs nor can strictly depend on one's own wealth or income.

In the American context, instead, justice related to healthcare services is not a principle referable to a subjective right that prevails on private property. It has a primary meaning that concerns individuals' economic capacity to fight in order to gain access to goods and services delivery. With this regard, it has been noticed that equal access to public healthcare interventions and practices is not compliant with the principle of justice. The most meaningful significance of justice in healthcare is considered a principle in support of private initiative 
and individuals' contractual capacities. Therefore, every public choice that provides services to everyone in accordance to his/her contributory capacity, or to his/her merit (according to a profile of personal qualities), or to free market trades is an ethically just practice.

Despite being a private good, the total costs of the service provided do not follow the classic market's rules. In some articles published on JAMA last March 2018, we can in fact read that

the US healthcare system is excessively costly is not news. The controversy involves 3 connected questions: (1) what are the real drivers of high costs, (2) what policies have the highest probability of reducing those costs, and (3) what are the consequences of not reducing excessive healthcare costs? (Emanuel, 2018, pp. 983-984)

Uwe Reinhardt (2014) was famous for answering the question about what drives high US healthcare costs with the assertion "It's the prices, stupid". Others scholar, such as Papanicolas and colleagues, essentially agree (Papanicolas, 2018, p. 1033). In a detailed analysis of healthcare spending in the United States and 10 other high-income, mainly European, countries, the authors found that the United States spends approximately twice as much on medical care.

This situation, however, is not justified by the market's rules, but we can think that it is a result that we have due to exasperated private competition, due to search for profits and economic successes. It is an effect of unbridled capitalism, of so-called "turbo capitalism" (Toose, 2018; Pagano \& Mangiacasale, 2018), that hurts individuals, that does not know solidarity, even if it brings many gains to some investor. All this has little to do with better health and with preferable idea of justice for health.

Starting from these observations, the meaning of justice, considered as public interventions that influence collective choices, assumes a residual role and refers to the principle of beneficence summarized in the expression "do to others their good". In light of previous considerations, the expression "do to others their good" means that the State is committed to deliver a minimum quantity of healthcare services, leaving in the hands of private resources free choice regarding the number as well as the level of the best healthcare services. That way of considering beneficence inspires marginal public health policies (as demonstrated by Medicare and Medicaid), because it gives to individual autonomous means to make choices related to healthcare (Casonato, 2012).

Nevertheless, behind the rhetorical appeal to individual's autonomy and to State's beneficence, there are various and different positions with respect to it is difficult to identify real voluntary choices, meaning that options are freely put in place without pressure or social-economic conditioning (Bassu, 2012).

From the framework described by Engelhardt, as well as from data provided by several researchers on issues related to the American healthcare system, it seems difficult maintaining that one could choose healthcare services in a way that is totally free from needs. The reason is that options are always irremediably conditioned by agents' economic status and are limited by insurance and working restrictions that represent the reference legal-economic framework.

Individual freedom and human rights stated by the United States Constitution, for example, do not explicitly envisage the right to health. Indirect evidence might be found in Articles 3 and 25 of the Universal Declaration of Human Rights with reference to the right to life, liberty and security of person (Art. 3) and to the right to a standard of living adequate for the health and well-being of himself/herself and of his/her family (Art. 25). 
On the background of a legal context which is flexible with regard to the right to health, different ways of healthcare services delivery are possible and, in this situation, the marketplace might be a regulatory element as well as an inspiring factor for healthcare policies.

However, these considerations do not preclude the feasible introduction of new rights and, in particular, of new subjective rights to protect health, even though it seems hard to state the fundamental right to health and to healthcare without a radical re-thinking of the American ethical-legal framework.

Analyzing by philosophical point of view, the American model and the Italian one, and reflecting on the bases of the principles of bioethics, it could be noticed that the supply of healthcare services in conformity with the free market, or in conformity exclusively with individual contributory capacities would be unjust (would be not preferable) only for the Italian model, since it is not compliant with the Constitution, sources of law, and principles of medical ethics.

If it is true that the right to health, considered as a fundamental subjective right, in the Italian model entails a core of "liberty rights" declinable with reference to bodily choices (which and how many health service, if and how undergoing therapies, etc.), it is also true that a contributory role is requested to citizens, except for the duty of public administration to guarantee primary care to everyone and free healthcare to indigents.

What can be observed, looking with the European eyes, is the diversity of concerns for the health system in the US. There is a lot of attention to topics, such as knowledge management practices in healthcare settings, or behavioral healthcare (Cummings, 2016).

In Italy, the attention paid to the health system is aimed at giving concrete form to the constitutional rules, in the face of emerging needs (such as, for example, palliative care or advanced directives).

Moreover, while in the US, there is great theoretical and philosophical attention to the health needs of different parts of the population (Indians, African Americans, women, the elderly, etc.), in Italy, there are no similar studies. This is explained both because the number and types of subjects are different, and because they are trying to overcome, again, paternalistic models.

American and Italian reflection shares the importance of the proliferation of subjective rights and, at the same time, the preoccupation that these rights not remain empty, rhetorical formulas (Wellman, 2018).

On the one hand, if, in the United States, the principle of autonomy has not given rise to subjective rights for health and for the health system, it has nevertheless made individuals responsible for the resources necessary to having and keeping a good level of health.

On the other hand, in Italy, there is the legal recognition of the right to health; the principle of autonomy is the prerequisite for extended access to health services, it does not concern the contractual or economic capacity of the subjects, but it is difficult to establish itself in the therapeutic relationship.

\section{Concluding Remarks: Philosophical Reflections About Healthcare Models: Right or Common Good?}

As it has been argued, the Italian healthcare model, more than the American one, seems to better balance providing everyone a minimum acceptable level of healthcare with the supply of health services depending on an individual's needs. Beyond the lights and shadows that characterize the investigated healthcare models, we have to come to the conclusion that healthcare policies, both at the private level and at the public one, could be 
considered just (Bobbio, 1995) ${ }^{16}$, preferable ${ }^{17}$, or, broadly speaking, to be promoted ${ }^{18}$ provided that they correspond to a "value assignment", meaning to a healthcare policy decision on what is worth to be promoted through the use of resources in a specific context.

However, recently in Europe, we are witnessing the review of health and healthcare as fundamental rights in order to support new legal interventions that consider health and healthcare as "common goods".

The concept of "common good" had a strong echo in the Anglo-Saxon contexts at the beginning of the 90's with Elinor Ostrom's first researches (Ostrom, 1990; Ostrom \& Charlotte, 2006; Deneulin \& Townsend, 2007; Somaa \& Vatnb, 2014). In Italy, some authors also work towards the increase of this category of goods that are neither totally public, nor totally referred to private subjects' management (Rodotà, 2013; Mattei \& Quarta, 2018; Seppilli, 2010).

In light of this concept, what consequences might emerge between defining "health" and "healthcare" differently? Is it really worth modifying the idea of "health" until it is considered a "common good"? This topic is a broader discussion. However, for the purpose of this paper, we can only notice that despite remarkable aspects, such as the empowerment of every agent, from public administration to citizens, and the distributed management of burdens and competencies according to the principles of equality and solidarity, treating "health" and "healthcare" as common goods would be dangerous. In particular, in the Italian context, it would entail the degradation of a fundamental right to a good, limiting its prescriptive capacity as well as institutional obligations. It should be verified, however, if a more responsible management of "common goods" is really cost-effective compared to the current healthcare system. After all, the Italian experience in treating specific goods as "common", such as water, despite the referendum in $2011^{19}$ and strong political activities, did not cause any normative changes or improvements. In fact, the Italian government in 2016 declared water to be privatized $^{20}$, regardless of the result of the referendum that ratified the popular will to consider water as a good distanced from market forces.

Probably, a different impact of the "common goods" might be supposed in the American model, even though it seems difficult to imagine an effective mobilization in the short period aimed at considering health a "common good".

However, we can conclude that in every healthcare model the stronger the claim of protection and guarantees that recognize health as a right (and also as a fundamental right), the lesser the economic-juridical-administrative obstacles to be faced. In the end, the idea that access to health services does not depend on individual income is just. This concept would in turn maximize public and private efforts to make healthcare management more equitable and preferable.

\footnotetext{
${ }^{16}$ Norberto Bobbio reminds the two classical meanings of justice, dated back to Aristotle. The meaning that identifies justice with legality considers just that action in compliance with the law. The other meaning identifies justice with equality and considers just the action, men, or law that establishes or respect a relationship based on equality.

17 On the concept of “justification”, see Scarpelli (1986).

18 Ibidem.

19 On June 12 and 13, 2011 in Italy was conducted a referendum to abrogate those laws imposing the privatization of water and the related services. The referendum obtained the quorum made by the $50 \%$ plus one voter, thus it abrogated the laws in question.

20 See legislative decree n. 175/2016, Testo unico in materia di società a partecipazione pubblica, at http://www.gazzettaufficiale.it/eli/id/2016/09/8/16G00188/sg. Retrieved 2-15-2019.
} 


\section{References}

AMA. (2017). AMA vision on healthcare reform. Retrieved February 15, 2019, from http://ama-assn.org/delivering-care/patient-support-advocacy/ama-vision-health-care-reform

Andersen, R. M., Rice, T. H., \& Kominski, G. F. (Eds.). (2007). Changing the US healthcare system: Key issues in health services policy and management. San Francisco: Jossey-Bass.

Aramini, M. (2009). Introduzione alla bioetica. (Introduction to Bioethics). Milano: Giuffré.

Atlas, S. W. (2011). In excellent health: Setting the record straight on America's healthcare. Stanford: Hoover Institution Press.

Austin, A., \& Hungerford, T. L. (2009). The market structure of the health insurance. Washington, DC: Congressional Research Service.

Bassu, C. (2012). La riforma sanitaria negli Stati Uniti d'America: un modello federale di tutela della salute? (Healthcare reform in the United States of America: a federal model of health protection? )In (G. G. Carboni, Ed.). La salute negli Stati composti. Tutela del diritto e livelli di governo. (Health in the Countries. Protection of Law and Levels of Government). Torino: Giappichelli.

Beauchamp, T. L., \& Childress, J. F. (2013). Principles of biomedical ethics. New York: Oxford University Press.

Bobbio, N. (1995). Eguaglianza e libertà. (Equality and Freedom). Torino: Einaudi Editore.

Borsellino, P. (2018). Bioetica tra “morali” e diritto. (Bioethics Between “Morals” and Law). Milano: Raffaello Cortina Editore.

Brock, D. W., Daniels, N., \& Callahan, D. (1989). Justice, healthcare, and the elderly. Philosophy \& Public Affairs, 18(3), 287-312.

Casonato, C. (2012). I sistemi sanitari. Note di comparazione. (Healthcare systems. Comparison notes). In G. G. Carboni (Ed.), La salute negli Stati composti. Tutela del diritto e livelli di governo. (Health in the Countries. Protection of Law and Levels of Government). Torino: Giappichelli.

Chiodi, M. (2005). Modelli teorici in Bioetica. (Theoretical models in Bioethics). Milano: Franco Angeli.

Cipolla, C. (2007). Manuale di sociologia della salute. (Handbook of Sociology of Health). Milano: Franco Angeli.

Cummings, N. (2016). Psyche's prophet: The selected writings of Nicholas A. Cummings. London: Routdelge.

Daniels, N., \& Sabin, J. (1997). Limits to healthcare: Fairs procedures, democratic deliberation and the legitimacy problem for insures. Philosophy \& Public Affairs, 26(4), 303-350.

Daniels, N. (2010). Justice, health and healthcare. The American Journal of Bioethics, 1(2), 2-16.

Dawes, D. (2016). 150 Years of Obamacare. Baltimore: John Hopkins University Press.

De Belvis, A. G., Ferrè, F., Specchia, M. L., Valerio, L., Fattore, G., \& Ricciardi, W. (2012). The financial crisis in Italy: Implications for the healthcare sector. Health Policy, 106(1), 10-16.

De Navas-Walt, C., Proctor, B., \& Smith, J. (2013). Income, poverty and health insurance coverage in the United States. Washington DC: U.S. Census Bureau, U.S. Government Printing Office.

Deneulin, S., \& Townsend, N. (2007). Public goods, global public goods and the common good. International Journal of Social Economics, 34(1-2), 19-36.

Emanuel, E. (2018). The real cost of the US healthcare system. JAMA, 319 (10), 983-984.

Engelhardt, H. T. Jr. (2001). The foundations of bioethics. New York: Oxford University Press.

Ferrajoli, L. (2001). Diritti fondamentali. Un dibattito teorico. (Fundamental Rights. A Theoretical Debate). Roma - Bari: Laterza.

Ferrajoli, L. (2007). Principia Iuris. Teoria del diritto e della democrazia. Vol I.(Principia Iuris. Theory of Law and Democracy). Roma - Bari: Laterza.

Ferrajoli, L. (2013). Dei diritti e delle garanzie. (About Rights and Guarantees). Bologna: Il Mulino.

Ferrajoli, L. (2014). La democrazia attraverso i diritti. (Democracy Through Law). Roma - Bari: Laterza.

Ferrera, M. (Ed.). (2005). Welfare state reform in southern Europe fighting poverty and social exclusion in Italy, Spain, Portugal and Greece. London-New York: Routledge.

Forni, L. (2016). La sfida della giustizia in sanità. Salute, equità, risorse. (The Challenge of Justice in Healthcare System. Health, Equity, Resources). Torino: Giappichelli.

Hill, J. (2012). Obamacare: What's in it. Citizen's Topical Guide to Obamacare. Dallas, TX: Primedia eLaunch Publishing.

Kleinman, A. (1981). Patients and healers in the contest of culture: An exploration of the borderland between anthropology, medicine and psychiatry. London: University of California Press.

Lamb, D. (1995). Organ Transplants and Ethics. London: Routledge. 
Lamb, D. (1998). Death, Brain Death, and Ethics. London: Routledge.

Mattei, U. (2011). Beni comuni. Un manifesto. (Common Goods. A Project) Roma-Bari: Laterza.

Mattei, U., \& Quarta, A. (2018). Punto di svolta. Ecologia, tecnologia e diritto privato. Dal capitale ai beni comuni. (Turning point. Ecology, technology and private law. From capital to common goods). Arezzo, Italy: Sansepolcro.

Morley-Fletcher, E. (2013). Modelli sanitari a confronto: Nuovi assetti istituzionali europei evidenziati dal dibattito sull'Obamacare. (Comparative healthcare models: New European institutional arrangements highlighted by the debate on the Obamacare). In R. Nania (Ed.), Attuazione e sostenibilità del diritto alla salute (pp. 127-171). (Implementation and Sustainability of the Right to Health). Roma: Sapienza Università Editrice.

Muehlebach, A. (2012). The moral neoliberal: Welfare and citizenship in Italy. Chicago-London: University of Chicago Press.

Obama, B. (2016). United States healthcare reform: Progress to date and next steps. JAMA, 316(5), 525-532.

Oberlander, J. (2009). Great expectations-The Obama administration and healthcare reform. The New England Journal of Medicine, 360, 321-323.

Ostrom, E. (1990). Governing the commons: The evolution of institutions for collective action. Cambridge, UK: Cambridge University Press.

Ostrom, E., \& Charlotte, H. (2006).Understanding knowledge as a commons: From theory to practice. Cambridge: The MIT Press.

Pagano, U., \& Mangiacasale, A. (2018). Temporality and consumption in post-modern societies: Ontologies, paradoxes. Lecce: Youcanprint.

Pence, G. (2004). Classic cases in medical ethics: Accounts of cases that have shaped medical ethics, with philosophical, legal, and historical backgrounds. Boston, Mcgraw-Hill.

Pessina, A. (2000). Bioetica. L'uomo sperimentale. (Bioethics. The Experimental Man). Milano: Bruno Mondadori.

Pozgar, G. (2012). Legal aspects of healthcare administration. Sudbury: Jones \& Bartlett Learning.

Reagan, M. (1999). The accidental system. New York: Routledge.

Reinhardt, U. E. (2014). Healthcare price transparency and economic theory. JAMA, 312(16), 1642-1643.

Rodotà, S. (2013). Il terribile diritto. Studi sulla proprietà privata e i beni comuni. (The tremendous right. Studies on private property and common goods). Bologna: Il Mulino.

Scarpelli, U. (1986). Gli orizzonti della giustificazione. (The Horizons of Justification) In L. Gianformaggio and E. Lecaldano (Ed.), Etica e diritto. (Ethics and Law). Roma-Bari: Laterza.

Sen, A. (2009). The idea of justice. London: Penguin Book.

Seppilli, T. (2010). Salute e sanità come beni comuni. Per un nuovo sistema sanitario. (Health and healthcare as common goods. For a new health system). ESPS, 33(4), 369-381.

Singer, P. (1995). Rethinking Life and Death. Oxford: Oxford University Press.

Singer, P. (2001). Writings on an Ethical Life. London: Fourth Estate.

Somaa, K., \& Vatnb, A. (2014). Representing the common goods-Stakeholders vs. citizens. Land Use Policy, 41, 325-333.

Tooze, A. (2018). Neoliberism's world order. Dissent, 65(3), 132-136.

Turati, G. (2013). The Italian Servizio Sanitario Nazionale: A renewing tale of lost promises. In J. Costa Font and S. Greer (Eds.), Federalism and decentralization in European health and social care: Competition, innovation and cohesion (pp. 47-66). Basingstoke: Palgrave Macmillan.

Wellman, C. (2018). The proliferation of rights: Moral progress or empty rhetoric? London: Routledge. 